\title{
REDUÇÃO DA MAIORIDADE PENAL NO BRASIL: UMA ANÁLISE
}

\section{Stéphanie Lã Ferrari ${ }^{1}$}

Resumo: Este trabalho teve como objetivo incitar uma discussão sobre a eficácia da redução da maioridade penal no combate a criminalidade cometida por menores de idade. A metodologia empregada foi a pesquisa bibliográfica embasada em artigos de revistas especializadas, na lei, na doutrina acerca do tema proposto e nos endereços eletrônicos da Câmara dos Deputados e do Senado Federal. Verifica-se que a temática ganha destaque sempre que um crime grave é praticado por menores. É fundamental a participação da população, a fim de buscar opiniões e soluções para as questões relacionadas à da redução da maioridade penal. Percebe-se que o tema é polêmico e complexo e que uma abordagem holística, contextualizada no mundo moderno e globalizado em que vivemos, e alicerçada em fatos, valores e normas, se faz necessária para o alcance de um consenso sobre o tema, que ainda não há.

Palavras-chave: Menor de idade; Julgamento moral; Maioridade civil. Direito penal.

1 Graduanda do Curso de Direito/Faculdade de Direito de Cachoeiro de Itapemirim, Brasil. E-mail: laferrari.stephanie@gmail.com. 